\title{
Fjölskyldumiðuð atferlismeðferð fyrir of feit börn
}

\author{
- Samantekt á niðurstöðum meðferðar og langtímaniðurstöðum við tveggja ára eftirfylgd
}

Prúður Gunnarsdóttir ${ }^{1}$ lknir, Svavar Már Einarsson² sálfræðingur, Urður Njarðvík ${ }^{3}$ sálfræðingur, Anna Sigríður Ólafsdóttir ${ }^{4,6}$ næringarfræðingur, Agnes Björg Gunnarsdóttir ${ }^{5}$ lknir, Tryggvi Helgason ${ }^{6}$ læknir, Ragnar Bjarnason ${ }^{3,6} \mid æ k n i r$

\section{ÁGRIP}

Inngangur: Offita barna hefur aukist á undanförnum áratugum. Brýn pörf er á gagnreyndu meðferðarformi til að sporna gegn pessari próun og meðal annarra hefur fjölskyldumiðuð atferlismeðferð Epsteins mikið verið rannsökuð, en kallað hefur verið eftir rannsóknum í klínískum aðstæðum. Markmið pessarar rannsóknar var að kanna skammtíma- og eftirfylgdarárangur fjölskyldumiðaðrar atferlismeðferðar Epsteins í klínískum aðstæðum á Íslandi.

Efniviður og aðferðir: Úrtakið samanstóð af 84 of feitum börnum á aldrinum 8-13 ára og einu foreldri hvers barns. Sextíu og ein fjölskylda lauk 12 vikna meðferð sem dreifðist yfir 18 vikur og var peim pátttakendum fylgt eftir í tvö ár eftir að meðferð lauk. Fyrir og eftir meðferð var mæld hæð og pyngd barna, hreyfing, dagleg neysla ávaxta og grænmetis, blóðprýstingur og ýmis blóðgildi. Lagðir voru fyrir börnin sjálfsmatslistar til að meta andlega líðan og félagsfærni. Hæð og pyngd foreldra var mæld fyrir og eftir meðferð og einnig svöruðu foreldrar sjálfsmatslista fyrir punglyndi. Niðurstöður: Staðlaður líkamspyngdarstuðull barnanna lækkaði marktækt frá upphafi til loka meðferðar $(F(2,60)=110,31, p<0,001)$ og var árangri við̌haldið við eins $(F(2,60)=1,33, p=0,253)$ og tveggja ára $(F(2,60)=$ $3,19, p=0,079$ ) eftirfylgd. Blóðprýstingur lækkaði á meðferðartímabilinu (efri mörk: $t(59)=-2,01, p<0,05$, neðri mörk: $t(59)=-4,00, p<0,001)$ og lækkun varð á insúlín- $(t(22)=6,1, p<0,05)$, príglýseríð- $(t(22)=0,31$, $\mathrm{p}<0,05)$ og heildarkólesterólgildum í undirúrtaki $(\mathrm{t}(22)=0,35, \mathrm{p}<0,05)$. Við meðferð dró úr punglyndis- $(F(1,59)=6,67, p<0,05)$ og kvíðaeinkennum barnanna $(F(1,57)=4,54, p<0,05)$ og sjálfsmynd peirra styrktist $(F(1,59)=19,2, p<0,001)$. Lækkun varð á líkamspyngdarstuðli foreldra á meðferðartímabilinu $(F(1,59)=71,54, p<0,001)$ en hann hækkaði aftur við eins árs eftirfylgd $(F(1,59)=41,87, p<0,001)$. Pá dró úr punglyndiseinkennum foreldra við meðferðina $(F(1,60)=12,93, p<0,01)$.

Ályktun: Fjölskyldumeðferð Epsteins hafði fjölpætt jákvæð áhrif á pyngdarstöðu, andlega og líkamlega líðan bæði til skemmri og til lengri tíma í úrtaki of feitra íslenskra barna.
'Department of Pediatrics, University of Colorado Denver, ${ }^{2} \mathrm{BUP}$ døgn - enhet for ungdom, Elverum, Sykehuset Innlandet, Norge, ${ }^{3}$ heilbrigðisvísindasviði, ${ }^{4}$ menntavísindasviði Háskóla Î́slands, ${ }^{5}$ Landspítala, ${ }^{6}$ Barnaspítala Hringsins, Landspítala.

Fyrirspurnir: Prúður Gunnarsdóttir thrudur.gunnarsdottir@ ucdenver.edu

Greinin barst 15. september 2013 , sampykkt til birtingar 30. janúar 2014.

\section{Inngangur}

Offita barna hefur aukist mikið víðsvegar í heiminum á undanförnum áratugum ${ }^{1}$ og eru Íslendingar par engir eftirbátar annarra pjóða. ${ }^{2}$ Offita hjá börnum getur haft alvarlegar líkamlegar og tilfinningatengdar afleiðingar, bæði til skemmri og lengri tíma, og rannsóknir hafa sýnt hærri tíðni ýmiskonar heilsutengds vanda meðal of feitra barna en meðal barna í kjörpyngd. Par má til dæmis nefna ýmsa áhættupætti hjarta- og æðasjúkdóma og sykursýki II, eins og hækkuð príglýseríð, fastandi insúlín og blóðprýstingur, en einnig aukin tíðni ýmiss sálfélagslegs vanda eins og punglyndis, kvíða og lélegrar sjálfsmyndar. ${ }^{3-6}$ Pví eru ríkar ástæður fyrir að takast á við offitu barna.

Mikilvægt er að bjóða upp á áhrifaríka meðferð en síðustu áratugi hefur aukin áhersla verið lögð á að meðferðarúrræði sem boðið er upp á almennt á vegum heilbrigðispjónustunnar séu gagnreynd. ${ }^{7}$ Til gagnreyndrar meðferðar (empirically supported treatment) telst hver sú meðferð sem sýnt hefur verið fram á með vísindalegum vinnubrögðum að bæti heilsu sjúklinga ${ }^{8}$ en til pess að teljast til gagnreyndrar meðferðar verður meðferð að hafa sýnt árangur umfram lyfleysu, lyf eða aðra meðferð. Tvö óháð rannsóknarteymi purfa að hafa rannsakað árangur af meðferðinni, rannsóknir purfa að hafa verið gerðar eftir handbók um meðferðina og pað parf að hafa komið skýrt fram hvað er einkennandi fyrir pað pýði sem rannsóknir hafa beinst að. ${ }^{9}$

Ein meðferð með sérlega péttan rannsóknagrunn er fjölskyldumiðuð atferlismeðferð Epsteins og félaga fyrir of feit börn. Sú meðferð hefur verið í próun í rúmlega 30 ár og liggur mikill fjöldi rannsókna að baki. ${ }^{10,11}$ Sýnt hefur verið fram á gagnsemi meðferðarinnar bæði til skemmri tíma og til lengri tíma ${ }^{11}$ en stórum hópi pátttakenda $(n=185)$ úr pessari meðferð var fylgt eftir í 10 ár eftir að meðferð lauk og sýndu niðurstöður að árangur var betri í fjölskyldumeðferð en meðal samanburðarhóps. ${ }^{12,13}$

Flestar peirra rannsókna sem framkvæmdar hafa verið á meðferðinni hafa farið fram undir stjórn eins rannsóknarhóps (Epsteins og félaga) í tilraunaaðstæðum á rannsóknarstofu háskóla, par sem stór hluti peirra barna sem koma til greina til pátttöku er útilokaður vegna ýmisskonar annarra líkamlegra (til dæmis fötlun) og/eða andlegra kvilla (til dæmis punglyndi, kvíði, hegðunarvandi). ${ }^{14,15}$ Í slíkum aðstæðum er áhersla á innra réttmæti (að meðferðin virki í afmörkuðum aðstæðum) tekin fram yfir áherslu á ytra réttmæti (að meðferð gagnist fjölpættum hópi, eða jafnvel pýði peirra barna sem á meðferð purfa að halda). Fáar rannsóknir á pessari meðferð hafa verið gerðar í klínískum aðstæð- 
um, eða par sem aðstæður taka mið af pví sem gengur og gerist í almennum meðferðaraðstæðum par sem minni stjórn er höfð á utanaðkomandi páttum og hefur pví verið kallað eftir slíkum rannsóknum. ${ }^{16}$

Tvær rannsóknir voru framkvæmdar á áhrifum meðferðarinnar í klínískum aðstæðum í Bretlandi. Niðurstöður peirra rannsókna gáfu til kynna að foreldrar og börn væru sátt við meðferðina en árangur var ekki allskostar sambærilegur við niðurstöður Epsteins og félaga. ${ }^{1718}$ Lítil forrannsókn á fjölskyldumeðferð Epsteins og félaga var framkvæmd á Barnaspítala Hringsins árin 2005-2007. Sú rannsókn sýndi vænlegan árangur og var árangur mun betri en í Bretlandi. Breytingar á stöðluðum líkamspyngdarstuðli (LPS-SFS) í Bretlandi sýndu lækkun um 0,15-0,16 staðalfráviksstig, en niðurstöður forrannsóknarinnar sýndu lækkun um 0,32 staðalfráviksstig. ${ }^{19}$ Par sem úrtakið í forrannsókninni var mjög lítið, var markmið pessarar rannsóknar að athuga árangur með stærra úrtaki barna á Barnaspítala Hringsins, og par sem langtímaárangur er pað sem mestu máli skiptir pegar litið er til árangurs meðferðar var pátttakendum fylgt eftir í tvö ár eftir að meðferð lauk.

\section{Efniviður og aðferð̈ir}

\section{Dátttakendur}

Úrtakið samanstóð af 84 of feitum börnum á aldrinum 8-13 ára (46 drengir og 38 stúlkur), ásamt einu foreldri hvers barns. Offita er skilgreind sem of mikil fitusöfnun ílíkamanum og tengist fitusöfnunin tölfræðilega hærri líkum á ýmsum heilsutengdum vanda. ${ }^{20}$ Líkamspyngdarstuðull (LPS, Body Mass Index BMI) er oftast notaður til að skilgreina offitu og er hann reiknaður út frá hæð og pyngd samkvæmt formúlunni pyngd/hæð $\left(\mathrm{kg} / \mathrm{m}^{2}\right)$. Alpjóðaheilbrigðismálastofnunin (World Health Organization, WHO) skilgreinir offitu meðal fullorðinna (18 ára og eldri) út frá líkamspyngdarstuðli 30 eða hærri. ${ }^{20}$ Meðal barna eru sérstakir staðlar fyrir aldur og kyn í samræmi við skilgreiningu á offitu samkvæmt alpjóðateymi um offitu (International Obesity Taskforce). ${ }^{21} Æ$ Æskilegur líkamspyngdarstuðull barna er breytilegur eftir aldri og kyni og pví er notast við staðlaðan líkamspyngdarstuðul eða staðalfráviksstig líkamspyngdarstuðuls (LPS-SFS) við greiningu á offitu barns. LPS er pá umreiknaður í staðalfráviksstig undir normaldreifingu par sem meðaltal er 0 og staðalfrávik er 1 og er LPS barns pá sem samsvarar +2 staðalfráviksstigum sambærilegur við LPS=30 hjá fullorðnum og flokkast með offitu.

Pátttakendur voru valdir í rannsóknina með aðstoð skólahjúkrunarfræðinga á höfuðborgarsvæðinu og purftu börnin að hafa staðlaðan líkamspyngdarstuðul (LPS-SFS) hærri en 2,0 staðalfráviksstig fyrir ofan meðaltal. Náðu öll börn viðmiðum um offitu (LPS-SFS, meðaltal=3,11 SFS, spönn=2,14-4,59). Meðalaldur barna við upphaf meðferðar var 11,0 ár $(S f=1,4$, spönn=7,5-13,6). Meirihluti foreldra sem tóku pátt voru mæður (74/84) og var meðalaldur peirra 40,3 ár (sf=5,4, spönn=28-54). Af peim foreldrum sem tóku pátt voru 83,4\% annaðhvort of pung eða of feit (LPS fullorðinna 225) og 31\% foreldra höfðu háskólamenntun en 21,4\% höfðu lokið skyldunámi. Einstæðir foreldrar voru 26,2\%. Frekari lýsingu á einkennandi páttum úrtaksins er að finna í grein Prúðar Gunnarsdóttur og félaga. ${ }^{22}$ Leyfi fékkst frá vísindasiðanefnd fyrir rannsókninni, leyfisnúmer: VSNb2012010028/03.7.

\section{Mrlingar}

Veggfastur, stafrænn hæðarmælir, Ulmer stadiometer (Busse Design+Engineering $\mathrm{GmbH}$, Elchingen, Pýskaland) var notaður til að mæla hæð og tölvustýrð vog frá Marel, Type C2 (Marel Reykjavík, Ísland) til að mæla pyngd barna og foreldra. LPS (kg/ $\mathrm{m}^{2}$ ) var reiknaður út frá niðurstöðum hæðar- og pyngdarmælinga og miðað var við sænska vaxtarkúrfu fyrir LPS ${ }^{23}$ svo hægt væri að finna út staðlaðan LPS barna (LPS-SFS) að teknu tilliti til aldurs og kyns. Hæð og pyngd var mæld fyrir og eftir meðferð og við eins og tveggja ára eftirfylgd.

Mælingar voru gerðar á daglegri hreyfingu og ávaxta- og grænmetisneyslu barna og foreldra viku áður en meðferð hófst og aftur í síðustu viku meðferðar. Voru börn og foreldrar beðin um að skrá niður alla hreyfingu sem átti sér stað utan skólatíma sem varði lengur en fimm mínútur og krafðist að minnsta kosti miðlungs áreynslu. Meðaltal fyrir daglega hreyfingu var reiknað út frá samanlögðum mínútum af hreyfingu yfir alla vikuna. Til pess að meta réttmæti hreyfingarskráningar áður en meðferð hófst var reiknuð fylgni milli hreyfingar pá viku og fyrstu viku í meðferð $(r=0,39, p<0,01)$, sem og fylgni milli skráðrar hreyfingar fyrir meðferð og spurningar á spurningalista um pátttöku í ípróttum $(\mathrm{r}=0,25, \mathrm{p}<0,05) .{ }^{22}$ Öll ávaxta- og grænmetisneysla pátttakenda var skráð og meðaltalsneysla á dag var reiknuð út. Réttmæti peirrar skráningar hefur ekki verið metið.

Mittismál barna var mælt með málbandi (ekki teygjanlegt) með sentimetrakvarða, fyrir og eftir meðferð. Námundað var að heilum og hálfum sentimetra.

Blóðprýstingur barna sem tóku pátt í rannsókninni var mældur fyrir og eftir meðferð með sjálfvirkum blóðprýstingsmæli af gerðinni Omron M6 (HEM-7001-E; Omron Healthcare lo., Ltd) og var hann skráður sem meðaltal priggja mælinga.

Fastandi blóðprufur voru framkvæmdar á hluta barnanna fyrir og eftir meðferð (sjálfvalið úrtak: öllum börnum var boðið að fara í blóðprufur og beiðni var afhent en einungis hluti pátttakenda nýtti sér boðið og fór í blóðprufurnar) par sem mældur var blóðhagur, CRP, ASAT, ALAT, heildarkólesteról, príglyseríðar og fastandi insúlín.

Prír sjálfsmatskvarðar voru fylltir út af börnum (fyrir og eftir meðferð og við eins- og tveggja ára eftirfylgd): punglyndiseinkenni barna voru metin með Children's Depression Inventory (CDI), ${ }^{24}$ Multidimensional Anxiety Scale for Children (MASC) ${ }^{25}$ var notaður til að meta einkenni kvíða og Piers-Harris Children's self concept scale $(\mathrm{PH})^{26}$ til að meta sjálfsmynd. Próffræðilegir eiginleikar CDI og MASC eru taldir ásættanlegir ${ }^{25,27,28}$ og sama niðurstaða hefur fengist á íslenskri útgáfu kvarðanna. ${ }^{29,30}$ Áreiðanleiki PH-listans er með ágætum í erlendri útgáfu listans. ${ }^{26}$ Listinn var pýddur og bakpýddur fyrir pessa rannsókn en próffræðilegir eiginleikar listans hafa ekki verið kannaðir á Íslandi.

The Social Skills Rating System (SSRS) var notaður (fyrir og eftir meðferð) til að meta félagsfærni barna en sá kvarði metur jafnframt hegðunarvandamál og námsárangur. ${ }^{31}$ Kvarðinn er fylltur út af börnum, foreldrum og kennara barnsins. Listinn hefur góða próffræðilega eiginleika í enskri útgáfu ${ }^{31}$ en fyrir pessa rannsókn var listinn pýddur á íslensku og bakpýddur. Próffræðilegir eiginleikar íslenskrar útgáfu hans hafa ekki verið metnir.

The Beck Depression Inventory, Second Edition ${ }^{32}$ var notaður til að meta möguleg punglyndiseinkenni hjá foreldrum fyrir og eftir 
meðferð og við eins og tveggja ára eftirfylgd. Próffræðilegir eiginleikar upprunalegrar útgáfu listans eru ásættanlegir ${ }^{32}$ og sýna rannsóknir að próffræðilegir eiginleikar íslenskrar gerðar listans eru góðir og sambærilegir við frumgerðina. ${ }^{33}$

\section{Framkvæmd}

Skólahjúkrunarfræðingar voru fengnir til að hafa samband við foreldra barna 8 ára og eldri sem náðu viðmiði um LPS-SFS hærra en 2,0 yfir meðaltali í reglubundinni skimun (hæðar og pyngdarmælingar í skólum) og bjóða peim að kynna sér meðferðina. Útilokandi pættir fyrir pátttöku voru alvarleg greindarskerðing barns, offita af læknisfræðilegum orsökum og alvarlegar takmarkanir fyrir einhverskonar fæðu eða hreyfingu. Auk pess mátti hvorki barn né foreldri vera pátttakandi í annarri meðferð við offitu. Haft var samband við 115 fjölskyldur á höfuðborgarsvæðinu (Reykjavík og nágrenni). Alls kom 91 fjölskylda í inntökuviðtal á Barnaspítala Hringsins og gáfu bæði foreldrar og börn upplýst sampykki sitt fyrir að taka pátt í meðferðinni. Ein fjölskylda var útilokuð frá pátttöku og sex aðrar hættu við áður en meðferð hófst. Alls hófu 84 fjölskyldur meðferð en 23 börn hættu pátttöku áður en meðferð lauk (27,4\%). 61 barn lauk meðferð og eftirfylgd við eitt og tvö ár. Um einkennandi pætti peirra sem hættu pátttöku áður en meðferð lauk má lesa í greinum Prúðar Gunnarsdóttur og félaga frá 2011 og 2012.34,35

Meðferðin var fjölskyldumiðuð atferlismeðferð Epsteins og félaga ${ }^{11}$ sem búið var að pýða og aðlaga að íslenskum aðstæðum. Nákvæma lýsingu á upphaflegri meðferð má sjá í grein Epsteins og félaga ${ }^{36}$ og pýðingu og aðlögun meðferðarinnar að íslenskum aðstæðum í grein Prúðar Gunnarsdóttur og félaga. ${ }^{19}$ Meðferðin er hönnuð fyrir börn á aldrinum 8-12 ára og er skilyrði fyrir pátttöku barns að minnsta kosti eitt foreldri sé tilbúið til að taka pátt. Meðferðin (12 vikur) var veitt yfir 18 vikna tímabil á Barnaspítala Hringsins á árunum 2007-2008. Fyrstu 8 vikurnar mættu barn og foreldri saman í hverri viku á Barnaspítala Hringsins. Eftir 8 vikur mættu barn og foreldri saman aðra hverja viku í prjú skipti og síðustu tímarnir voru svo að mánuði liðnum. Allar meðferðarvikurnar mættu barn og foreldri saman tvisvar sinnum í viku; annan tímann í einstaklingsráđgjöf en hinn í hóptíma. Í einstaklingstímum (15-30 mínútur) fór fram vigtun og farið var yfir skráningu á hreyfingu og mataræ miðum fylgt eftir. Ef markmiðunum var ekki náð var peim leiðbeint um hvað mætti betur fara en jafnframt hrósað fyrir pað sem vel var gert og fengu börnin punkta í hvatningarkerfi ef pau náðu settum markmiðum. Hóptímarnir (60-90 mínútur) voru aðskildir fyrir foreldra og börn en fóru fram á sama tíma. Í hóptímunum fór fram fræðsla og fengu pátttakendur lesefni heim sem tengdist pví efni sem tekið var fyrir hverju sinni. Meðferðarefnið samanstóð af 10 köflum í fræðsluhandbók fyrir foreldra og sambærilegum 10 köflum af fræðsluefni fyrir börnin og skiptist í fimm meginpætti. Í fyrsta hluta var fjallað um hvernig má ná fram pyngdarstjórnun og viðhalda pyngdartapi. Í öðrum hluta var farið yfir ráðleggingar um heilsusamlegt mataræði. Í priðja hluta var farið yfir leiðir til að skapa heilsusamlegra umhverfi fyrir börnin til að stuðla að bættu mataræði og aukinni hreyfingu. Í fjórða hluta voru kenndar aðferðir til að breyta hegðun og í fimmta hluta aðferðir til að viðhalda breyttri hegðun. Mikilvægur hluti af meðferðinni er atferlismótun barns með hvatningarkerfum og annarri skilmála- stjórn, en stórt hlutfall af hóptímum með foreldrum fer í kennslu á peim páttum. Beinist atferlismótun að pví draga úr kyrrsetu, auka daglega hreyfingu, bæta mataræði og breyta hegðunarskilmálum í umhverfinu svo að peir verði hliðhollari breyttum lífsvenjum.

\section{Úrvinnsla}

Notast var við tölfræðiforritið PASW S Statistics 18, útgáfu 18.00 (SPSS, Inc., 2009, Chicago IL) við úrvinnslu gagna. Lýsandi tölfræði er gefin fyrir meðaltöl, staðalfrávik og fjölda athugana. Pöruð $t$ próf og endurtekin einbreytudreifigreining var gerð til að meta áhrif af meðferð. Meginniðurstöður rannsóknarinnar (pyngdartap meðan á meðferð stóð og við eins og tveggja ára eftirfylgd) voru settar fram sem breyting á staðalfráviksstigum líkamspyngdarstuðuls ( $\triangle$ LPS-SFS). Niðurstöður á sálfræðilegum mælingum voru gefnar upp sem breytingar á stigum á peim matslistum sem lagðir voru fyrir. Niðurstöður fyrir daglega hreyfingu voru settar fram sem fjöldi mínútna á dag sem varið var í hreyfingu og dagleg neysla ávaxta- og grænmetis sem skammtar á dag af bæði ávöxtum og grænmeti. Fyrir blóðgildi var reiknað hversu hátt hlutfall var yfir fyrirfram ákveðnum viðmiðunargildum bæði fyrir og eftir meðferð. (Viðmiðunargildi: Kólesteról $\geq 5,0$ mmól/L; Príglýseríð $\geq 1,6$ mmól/L; Insúlín $\geq 23 \mathrm{mU} / \mathrm{L}$; ASAT og ALAT $\geq 40 \mathrm{U} / \mathrm{L}$ ). Í öllum marktektarprófum var miðað við öryggisbil 95\% og alfastuðul $(\alpha)=0,05$.

\section{Niðurstöður}

Lýsandi tölfræði fyrir börn og foreldra í rannsókninni sést í töflu I. Pátttakendur voru við upphaf meðferðar 84 of feit börn (spönn fyrir LPS-SFS=2,14-4,59) á aldrinum 6 til 13 ára. Af pessum fjölda voru 30 stúlkur og 31 drengur sem luku meðferð auk pess að mæta í eins og tveggja ára eftirfylgd. Blóðhagur var mældur við upphaf meðferðar (fjöldi barna fyrir hverja mælingu var á bilinu 53-74) (sjá í töflu I). Af pessum börnum voru 24,6\% yfir viðmiðunargildi á kólesteróli, 18,9\% voru yfir viðmiðunargildi á príglýseríðum og 20,6\% á insúlíni. Lægra hlutfall var yfir viðmiðunargildum á ASAT, eða 8,2\%, og ALAT 12,2\%. Yfir helmingur peirra foreldra sem tóku pátt (53,6\%) náði viðmiði fyrir alvarlega offitu (viðmið fullorðina LPS $\geq 40)$.

Í töflu II sjást breytingar á LPS-SFS barna fyrir og eftir meðferð og við eftirfylgd einu og tveimur árum eftir að meðferð lauk. LPS-SFS barnanna lækkaði marktækt frá upphafi meðferðar til loka hennar (meðaltalsmunur=0,39 staðalfráviksstig (SFS), sf=0,29, $\mathrm{F}(2,60)=110,31, \mathrm{p}<0,001)$ og enn fremur var árangri viðhaldið við eins $(\mathrm{F}(2,60)=1,33, \mathrm{p}=0,253)$ og tveggja ára eftirfylgd $(\mathrm{F}(2,60)=3,19$, $\mathrm{p}=0,079)$. LPS foreldra lækkaði marktækt frá upphafi til loka meðferðar $(\mathrm{F}(1,59)=71,54, \mathrm{p}<0,001)$ en hækkaði svo marktækt aftur við eins árs eftirfylgd $(\mathrm{F}(1,59)=41,87, \mathrm{p}<0,001)$.

Mittismál barna lækkaði marktækt úr 96,05 cm að meðaltali fyrir meðferð í 89,9 cm að meðaltali eftir að meðferð lauk $(\mathrm{t}(60)=10,47$, $\mathrm{p}<0,001)$.

Hjá peim börnum (tafla II) par sem blóðmælingar voru framkvæmdar bæði fyrir og eftir meðferð $(n=23)$ má sjá að marktæk lækkun varð á kólesteróli $(\mathrm{t}(22)=0,35, \mathrm{p}<0,05)$ og á príglýseríðum $(\mathrm{t}(22)=0,31, \mathrm{p}<0,05)$. Sömuleiðis lækkaði insúlíngildi marktækt $(\mathrm{t}(22)=6,10, \mathrm{p}<0,05)$. Ekki var marktækur munur á ALAT- og ASATgildum fyrir og eftir meðferð. Hreyfing barna jókst að meðaltali 
Tafla I. Lýsandi tölfræði við upphaf meðferðar fyrir foreldra og börn sem tóku pátt í rannsókninni.

\begin{tabular}{|c|c|}
\hline & $\begin{array}{l}\text { Heildarfjöldi }(n=84), \text { hlutfall }(\%) \\
\text { Meðaltal } \pm \text { staðalfrávik }\end{array}$ \\
\hline \multicolumn{2}{|l|}{ Börn } \\
\hline Stúlkur ( $n=38)$ & 45,2 \\
\hline Drengir $(n=46)$ & 54,8 \\
\hline Aldur (ár) & $10,6 \pm 1,4$ \\
\hline Pyngd (kg) & $66,1 \pm 12,8$ \\
\hline Нæð (cm) & $151,1 \pm 10,0$ \\
\hline Staðlaður LPS & $3,1 \pm 0,5$ \\
\hline Kólesteról $(n=53)^{\star}$ & 24,5 \\
\hline Príglýseríð $(n=53)^{*}$ & 18,9 \\
\hline Insúlín $(n=68)^{*}$ & 20,6 \\
\hline $\operatorname{ASAT}(n=73)^{*}$ & 8,2 \\
\hline ALAT $(n=74)^{*}$ & 12,2 \\
\hline \multicolumn{2}{|l|}{ Foreldrar } \\
\hline Konur $(n=74)$ & 88,1 \\
\hline Karlar $(n=10)$ & 11,9 \\
\hline Aldur & $40,3 \pm 5,4$ \\
\hline \multicolumn{2}{|l|}{ LPS flokkun } \\
\hline Kjörpyngd (n=14) & 16,7 \\
\hline Yfirpyngd $(n=25)$ & 29,8 \\
\hline Offita $(n=45)$ & 53,6 \\
\hline \multicolumn{2}{|l|}{ Menntun } \\
\hline Grunnskólamenntun ( $n=18)$ & 21,4 \\
\hline Iðnmenntun (n=40) & 47,6 \\
\hline Háskólamenntun ( $\mathrm{n}=26)$ & 31 \\
\hline Einstæðir foreldrar $(n=22)$ & 26,2 \\
\hline
\end{tabular}

*Hlutfall barna yfir viðmiðunargildum (viðmiðunargildi: s-Kólesteról =5,0; s-Príglýseríðar

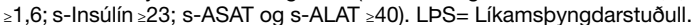

um 20,8 mínútur á dag frá upphafi til loka meðferðar $(\mathrm{t}(60)=9,42$, $\mathrm{p}<0,001)$. Dagleg neysla ávaxta og grænmetis jókst um tæplega einn og hálfan skammt á dag frá upphafi til loka meðferðar $(\mathrm{t}(60)=7,51, \mathrm{p}<0,001)$.

Blóðprýstingur barnanna $(n=60)$ lækkaði frá upphafi til loka meðferðar (tafla II). Á slagbilsprýstingi (efri mörkum) má sjá meðaltalslækkun um 2,3 mm/Hg (t(59)=-2,01, p<0,05) og á hlébilsprýstingi (neðri mörkum) var lækkunin að meðtaltali $4,1 \mathrm{~mm} / \mathrm{Hg}$ $(\mathrm{t}(59)=-4,00, \mathrm{p}<0,001)$.

Tafla III sýnir breytingar á mælingum á andlegri líðan barna. Við meðferð lækkaði skor á punglyndiskvarða marktækt $(\mathrm{F}(1,59)=6,67$, $\mathrm{p}<0,05)$ og sömuleiðis skor á kvíðakvarða $(\mathrm{F}(1,57)=4,54, \mathrm{p}<0,05)$ peirra barna sem tóku pátt. Pessum breytingum var viðhaldið við eins og tveggja ára eftirfylgd. Sjálfsmynd barnanna styrktist frá upphafi meðferðar til loka hennar $(\mathrm{F}(1,59)=19,2, \mathrm{p}<0,001)$ og hélt áfram að styrkjast við eins- $(\mathrm{F}(1,59)=6,43, \mathrm{p}<0,05)$ og tveggja ára $(\mathrm{F}(1,59)=7,6, \mathrm{p}<0,01)$ eftirfylgd. Félagsfærni varð betri frá upphafi meðferðar til loka hennar samkvæmt mati barnanna sjálfra $(t(60)=2,68, p<0,01)$, foreldra peirra $(t(60)=2,32, p<0,05)$ og kennara $(t(52)=2,4, p<0,05)$. Við meðferð dró úr punglyndiseinkennum foreldra $(\mathrm{F}(1,60)=12,93, \mathrm{p}<0,01)$ og peim breytingum var viðhaldið við eins- og tveggja ára eftirfylgd $(\mathrm{p}>0,05)$.

\section{Umræða}

Markmið pessarar rannsóknar var að kanna langtímaárangur af fjölskyldumeðferð Epsteins og félaga í klínískum aðstæðum á Íslandi. Niðurstöður sýndu marktækan mun á stöðluðum líkamspyngdarstuðli barna fyrir og eftir meðferð og var peim árangri viðhaldið við eins og tveggja ára eftirfylgd. Í forrannsókn Prúðar og félaga ${ }^{19}$ á pessari sömu meðferð fengust sambærilegar niðurstöður með tilliti til lækkunar á stöðluðum líkamspyngdarstuðli barna á meðan á meðferð stóð. Par sýndu niðurstöður lækkun á stöðluðum líkamspyngdarstuðli barna frá upphafi til loka meðferðar upp á 0,32 staðalfráviksstig par sem peirri lækkun var viðhaldið til priggja mánaða. Í pessari rannsókn var lækkunin 0,39 staðalfráviksstig og var henni viðhaldið til tveggja ára sem gefur til kynna góð langtíma meðferðaráhrif í átt að pví sem fram hefur komið í rannsóknum Epsteins og félaga. ${ }^{12,13}$ Í fyrri rannsókninni var samanburðarhópur sem fékk hefðbundna meðferð á Barnaspítalanum eða viðtöl við næringarfræðing og sérfræðing í efnaskiptasjúkdómum barna. Engin lækkun varð á stöðluðum líkamspyngdarstuðli barna í samanburðarhópi í peirri rannsókn, sem er í samræmi við aðrar rannsóknir sem hafa sýnt að staðlaður líkamspyngdarstuðull barna lækkar sjaldnast og hækkar heldur án virkrar meðferðar. ${ }^{37,38}$ Niðurstöður pessarar rannsóknar, og pá sérlega sú niðurstaða að lækkun á líkamspyngdarstuðli barna viðhélst tveimur árum eftir að meðferð lauk, renna pví enn frekari stoðum undir gagnsemi meðferðar Epsteins í klínískum aðstæðum á Íslandi.

Í meðferðinni lækkaði líkamspyngdarstuðull foreldra frá upphafi til loka meðferðar. Meðferð bar pví ekki einungis árangur fyrir börnin heldur einnig fyrir foreldra. Niðurstöður úr eftirfylgd benda pó til pess að foreldrum hafi ekki gengið nægilega vel að viðhalda peim árangri, par sem peir pyngdust aftur að meðferð lokinni. Algengt er að fullorðnum einstaklingum gangi erfiðlega að viðhalda pyngdartapi ${ }^{14}$ og pví koma pessar niðurstöður ekki á óvart. Pessar niðurstöður færa pó sterk rök fyrir pví að boðið sé upp á offitumeðferð fyrir börn, sérstaklega í ljósi pess hversu góður árangur kom fram við eftirfylgd í pessari rannsókn. Börn eru að tileinka sér venjur sem tengjast mataræði og hreyfingu á meðan fullorðið fólk hefur oft á tíðum fastmótaðri venjur sem erfiðara getur verið að breyta. ${ }^{16}$

Breytingar á LPS-SFS sem áttu sér stað í pessari rannsókn ( LPS$\mathrm{SFS}=0,39$ ) voru meiri en í peim rannsóknum sem framkvæmdar voru í Bretlandi. ${ }^{1718}$ Niðurstöður bresku rannsóknanna sýndu að LPS-SFS barna lækkaði að meðaltali um 0,15-0,16 staðalfráviksstig. Sömuleiðis var árangur meiri en í forrannsókn hér á Íslandi ${ }^{19}$ en par varð lækkun sem nam 0,32 staðalfráviksstigum. Árangur var pó minni en í upprunalegum rannsóknum Epsteins og félaga ${ }^{11} 1$ Bandaríkjunum, en í peim rannsóknum hefur hátt hlutfall barna náð að lækka LPS-SFS um 0,50 staðalfráviksstig. Nokkrar ástæður gætu verið fyrir pessum mismun á árangri meðferðar. Ein af ástæðunum gæti verið menningarmunur og að útilokunarskilyrði fyrir pátttöku eru stífari í upprunalegu rannsóknunum. Í öðru lagi höfðu meðferðaraðilar og starfsfólk í upprunalegu rannsóknunum hlotið mikla pjálfun í veita pessa meðferð og höfðu sömuleiðis mikla reynslu af pví og pví geta meðferðarheilindi (treatment integrity) við notkun meðferðarefnis Epsteins og félaga haft áhrif á alhæfingargildi frá tilraunastofunni til klínískra aðstæðna par sem pjálfun starfsfólks var minni í notkun pessa meðferðarúrræð- 
Tafla II. Meðaltöl og staðalfrávik fyrir staðlaðan likamspyngdarstuðul, fyrir og eftir meðferð og við eins árs og tveggja ára eftirfylgd. Meðaltöl fyrir daglega hreyfingu, neyslu ávaxta og grænmetis, blóðprýsting, og blóðmælingar, fyrir og eftir meðferð. Meðaltöl fyrir líkamspyngdarstuðul foreldra fyrir og eftir meðferð og við eins árs eftirfylgd.

\begin{tabular}{|c|c|c|c|c|}
\hline & $\begin{array}{c}\text { Fyrir meðferð } \\
\text { Meðaltal } \pm \text { staðalfrávik }\end{array}$ & $\begin{array}{c}\text { Eftir meðferð } \\
\text { Meðaltal } \pm \text { staðalfrávik }\end{array}$ & $\begin{array}{l}\text { Við eins árs eftirfylgd } \\
\text { Meðaltal } \pm \text { staðalfrávik }\end{array}$ & $\begin{array}{l}\text { Við tveggja ára eftirfylgc } \\
\text { Meðaltal } \pm \text { staðalfrávik }\end{array}$ \\
\hline \multicolumn{5}{|l|}{ Börn } \\
\hline Staðlaður LPS ( $\mathrm{n}=61)$ & $3,11 \pm 0,5$ & $2,72 \pm 0,5^{\star \star \star}$ & $2,76 \pm 0,4$ & $2,65 \pm 0,72$ \\
\hline Mittismál (cm) (n=61) & $96,1 \pm 9,7$ & $89,9 \pm 9,6^{\star \star \star}$ & & \\
\hline Dagleg hreyfing (mínútur) & $13,8 \pm 8,7$ & $34,6 \pm 8,7^{\star \star \star}$ & & \\
\hline Dagleg ávaxta-grænmetisneysla (skammtar) & $1,41 \pm 0,7$ & $2,87 \pm 2,4^{\star \star \star}$ & & \\
\hline \multicolumn{5}{|l|}{ Blóðprýstingur (n=60) } \\
\hline Efri mörk & $115,9 \pm 8,9$ & $113,6 \pm 8,8^{*}$ & & \\
\hline Neðri mörk & $67,4 \pm 7,5$ & $63,3 \pm 7,3^{\star \star \star}$ & & \\
\hline \multicolumn{5}{|l|}{ Blóðmælingar (n=23) } \\
\hline Kólesteról & $4,55 \pm 0,7$ & $4,2 \pm 0,6^{\star}$ & & \\
\hline Príglýseríð & $1,25 \pm 0,5$ & $0,94 \pm 0,5^{\star}$ & & \\
\hline Insúlín & $20,14 \pm 12,0$ & $14,08 \pm 9,0^{\star}$ & & \\
\hline ASAT & $29,04 \pm 7,1$ & $27,17 \pm 4,2$ & & \\
\hline ALAT & $25,35 \pm 6,3$ & $24,09 \pm 6,5$ & & \\
\hline \multicolumn{5}{|l|}{ Foreldrar } \\
\hline LPS $(n=61)$ & $30,7 \pm 5,4$ & $29,2 \pm 5,2^{\star \star \star}$ & $30,3 \pm 5,2^{\star \star \star}$ & \\
\hline
\end{tabular}

${ }^{*} \mathrm{p}<0,05,{ }^{* *} \mathrm{p}<0,01,{ }^{* * *} \mathrm{p}<0,001, \mathrm{LPS}=$ Líkamspyngdarstuðull.

is. Til að kanna annars vegar hversu nákvæmlega meðferðarefni er fylgt í rannsóknum á fjölskyldumeðferð Epsteins og félaga, og hins vegar til að hægt sé að bera saman meðferðaráhrif milli ólíkra aðstæðna og menningarheima, væri æskilegt að mælt yrði hvernig staðið er að meðferðinni við frekari áhrifarannsóknir í framtíðinni.

Mikilvægi hreyfingar fyrir líkamlega og andlega heilsu er óumdeilanlegt og er pví jákvætt að sjá að ástundun hreyfingar í frítíma jókst hjá börnunum meðan á meðferð stóð. Atferlismótun meðan á meðferð stóð og hvatning til ástundunar hreyfingar hefur líklega haft mikið að segja. Einnig er hugsanlegt að aukin hreyfigeta barna vegna pyngdartaps hafi gert peim léttara fyrir og almennt aukið löngun peirra til að hreyfa sig. Annar páttur sem gæti átt pátt í að skýra aukningu á hreyfingu er pátttaka foreldra í meðferðinni. Foreldrar eru mikilvægar fyrirmyndir barna sinna pegar kemur að hreyfingu ${ }^{39}$ og 1 fjölskyldumeðferð eru foreldrar hvattir til að auka eigin hreyfingu og hafa fyrir börnum sínum góðar venjur í pessum efnum, sem og öðrum heilsutengdum páttum.

Pó mikil aukning hafi orðið á ávaxta- og grænmetisneyslu barnanna, eiga pau flest töluvert í land með að uppfylla lýðheilsuviðmið um fimm skammta af ávöxtum og grænmeti á dag. ${ }^{40}$ Skammtímarannsóknir sýna að fæða með lága orkupéttni eins og ávextir og grænmeti auka seddu og minnka svengdartilfinningu og par af leiðandi orkuinntöku. ${ }^{41}$ Öll aukning ávaxta- og grænmetisneyslu verður pví að teljast jákvæð og er ásamt aukinni hreyfingu líkleg til að bæta heilsu barnanna.

Blóðprýstingur barnanna lækkaði frá upphafi meðferðar til loka hennar. Rannsóknir sýna að regluleg hreyfing (30 mínútur á dag) getur lækkað blóðprýsting, jafnvel allt að $10 \mathrm{mmHg}{ }^{42}$ Einnig hefur mataræði áhrif á blóðprýsting og hafa rannsóknir sýnt að aukin neysla á kalíum og magnesíum sem finnast í ávöxtum og grænmeti

Tafla III. Meðaltöl fyrir mælingar á líðan barna fyrir og eftir meðferð og við eins árs og tveggja ára eftirfylgd. Meðaltöl fyrir punglyndisstig foreldra, fyrir og eftir meðferð og við eins og tveggja ára eftirfylgd. ${ }^{\dagger}$

\begin{tabular}{|c|c|c|c|c|}
\hline & $\begin{array}{c}\text { Fyrir meðferð } \\
\text { Meðaltal } \pm \text { staðalfrávik }\end{array}$ & $\begin{array}{c}\text { Eftir meðferð } \\
\text { Meðaltal } \pm \text { staðalfrávik }\end{array}$ & $\begin{array}{l}\text { Við eins árs eftirfylgd } \\
\text { Meðaltal } \pm \text { staðalfrávik }\end{array}$ & $\begin{array}{l}\text { Við tveggja ára eftirfylgd } \\
\text { Meðaltal } \pm \text { staðalfrávik }\end{array}$ \\
\hline \multicolumn{5}{|l|}{ Börn } \\
\hline Punglyndi (CDI) & $48,3 \pm 12,2$ & $44,9 \pm 8,1^{*}$ & $45,3 \pm 6,8$ & $45,9 \pm 6,5$ \\
\hline Kvíði (MASC) & $53,1 \pm 13,5$ & $49,9 \pm 9,9^{*}$ & $47,4 \pm 10,2$ & $46,1 \pm 12,1$ \\
\hline Sjálfsmynd (PH) & $57,2 \pm 12,4$ & $60,7 \pm 10,3^{\star \star \star}$ & $63,2 \pm 9,4^{*}$ & $65,6 \pm 8,7^{\star \star}$ \\
\hline Félagsfærni (SSRS) & $57,1 \pm 10,4$ & $59,8 \pm 10,0^{\star \star}$ & & \\
\hline Félagsfærnimat foreldra (SSRS) & $53,2 \pm 8,8$ & $55,4 \pm 9,3^{\star}$ & & \\
\hline Félagsfærnimat kennara (SSRS) & $41,2 \pm 9,5$ & $42,7 \pm 8,9^{*}$ & & \\
\hline \multicolumn{5}{|l|}{ Foreldrar } \\
\hline \multicolumn{5}{|l|}{ Punglyndi } \\
\hline (BDI-II) & $9,95 \pm 9,7$ & $6,93 \pm 10,2^{\star \star}$ & $5,95 \pm 10,1$ & $6,33 \pm 8,3$ \\
\hline
\end{tabular}

† Notast var við t-skor fyrir CDI (punglyndis) og MASC (kvíða) kvarða

${ }^{*} \mathrm{p}<0,05,{ }^{* *} \mathrm{p}<0,01,{ }^{* * *} \mathrm{p}<0,001$ 
hafi jákvæð áhrif á blóðprýsting. Meiri hreyfing og neysla ávaxta og grænmetis hjá börnum meðan á meðferð stóð og pyngdartap hefur pannig að öllum líkindum stuðlað að lægri blóðprýstingi peirra að meðferð lokinni.

Pegar niðurstöður blóðmælinga eru skoðaðar má sjá að umtalsverður hluti peirra barna sem komu til meðferðar var með hækkun á peim blóðgildum sem könnuð voru, umfram pað sem eðlilegt telst. Rannsóknir hafa sýnt að offita spáir fyrir um hærri líkur á sykursýki af tegund II og hjarta- og æðasjúkdómum. ${ }^{43}$ Einnig hafa fundist tengsl milli offitu og ýmissa áhættupátta fyrir hjarta- og æðasjúkdómum, eins og skert insúlínnæmi og blóðfitubrenglun. ${ }^{44}$ Í pessari rannsókn voru nokkur börn með hækkað fastandi insúlín sem leiðir til aukinnar áhættu á að próa með sér sykursýki af tegund II. Umtalsverður hluti var einnig með hækkað heildarkólesteról sem hefur sterk tengsl við próun hjarta- og æðasjúkdóma. ${ }^{44}$ Pótt fá börn hafi fengist í blóðmælingar fyrir og eftir meðferð er athyglisvert að sjá að jákvæðar breytingar sjást á blóðgildum peirra barna sem fóru í pessar mælingar bæði fyrir og eftir meðferð. Peim börnum sem eru með kólesteról og insúlín yfir viðmiðunarmörkum fækkar um helming. Petta eru jákvæð skilaboð um bætt ástand barnanna en ætti auk pess að vera góður hvati fyrir foreldra til að halda áfram á réttri braut eftir að fjölskyldumiðaðri atferlismeðferð lýkur.

Líðan peirra barna sem luku meðferð var betri í lok meðferðar en við upphaf hennar samkvæmt matslistum á punglyndi, kvíða og sjálfsmynd. Vissulega voru pó skor á matslistum fyrir punglyndis- og kvíðaeinkenni undir klínískum mörkum. Sömuleiðis jókst félagsfærni barnanna að mati peirri sjálfra, foreldra peirra og kennara. Рað er sérstaklega áhugavert að sjálfsmynd barnanna hélt áfram að styrkjast eftir að meðferð lauk við eins- og tveggja ára eftirfylgd og má leiða líkur að pví að vissir meðferðarpættir hafi ýtt undir eða aukið færni sem varð til pess að styrkja sjálfsmynd barnanna áfram eftir að meðferð lauk. Í klínískum úrtökum of pungra eða of feitra barna er tíðni geðrænna vandamála hærri en í almennum úrtökum barna sem glíma við ofpyngd eða offitu. ${ }^{3,35}$ Felst pessi munur meðal annars í hærri tíðni punglyndis og kvíða og jafnframt virðast of feit börn að jafnaði hafa minna sjálfstraust en jafningjar sem eru í kjörpyngd. ${ }^{3}$ Algengt er að of pung eða of feit börn verði fyrir stríðni og höfnun sem svo leiðir af sér verri líðan og námsframmistöðu. ${ }^{22}$ Petta er mikilvægt að hafa í huga par sem geðrænn vandi getur haft áhrif á árangur barna í offitumeðferð. ${ }^{35}$ Mikilvægt er pví að frekari rannsóknir fari fram á pví hvernig hægt er að sníða offitumeðferð að sértækum geðrænum vanda barna til pess að auka árangur. Í dag eru slíkar rannsóknir skammt á veg komnar.

Vissar aðferðafræðilegar takmarkanir eru á pessarari rannsókn og pá sérstaklega að ekki var til staðar samanburðarhópur, svo erfitt er að meta hvort pær breytingar sem áttu sér stað séu ólíkar peim er ef til vill hefðu átt sér stað hjá of pungum og of feitum börnum sem taka ekki pátt í meðferð miðaðri að pyngdarstjórnun. Pó má benda á, eins og áđur kom fram, að í forprófun Prúðar Gunnarsdóttur og félaga ${ }^{19}$ var til staðar lítill samanburðarhópur sem fylgt var eftir í eitt ár og hafði hlotið hefðbundna pjónustu á Barnaspítala Hringsins. Ekki urðu neinar breytingar á stöðluðum líkamspyngdarstuðli fyrir pann hóp. Vert er að taka fram að í pessari rannsókn var ekki notast við samanburðarhóp, par sem rannsakendum pótti ekki siðferðilega rétt að halda börnum frá meðferð við offitu í petta langan tíma, par sem fyrri rannsóknin á árangri meðferðarinnar hafði sýnt góðan árangur og par var samanburðarhópur sem fékk hefðbundna meðferð sem gerði lítið gagn. Rannsóknir benda jafnframt til pess að börn yfir kjörpyngd eigi pað til að pyngjast yfir tíma ${ }^{37,38}$ og eru pessar niðurstöður pví hvetjandi.

Að bjóða upp á fjölskyldumiðaða atferlismeðferð Epsteins og félaga fyrir fjölbreyttan hóp of feitra íslenskra barna virðist lofa góðu, bæði til skemmri og lengri tíma. Að baki pessa meðferðarúrræðis liggja fjölmargar erlendar rannsóknir og hefur pessi rannsóknarvinna hér á landi stuðlað að pví að nú er boðið upp á gagnreynt úrræði fyrir of feit íslensk börn. Göngudeild fyrir of feit börn er nú starfandi við Barnaspítala Hringsins á grunni pessara niðurstaðna par sem pverfaglegt teymi stýrir meðferð og fylgir eftir of feitum börnum og fjölskyldum peirra.

\section{Heimildir}

1. Wang $Y$, Lobstein T. Worldwide trends in childhood overweight and obesity. Int J Pediatr Obes 2006; 1: 11-25.

2. Brynhildur B. Breytingar á hæð og pyngd 9 ára barna Reykjavík 1919-1998. Óbirt MA ritgerð, Kennaraháskól Íslands 1999.

3. Wardle J, Cooke L. The impact of obesity on psychological well-being. Best Pract Res Clin Endocrinol Metab 2005; 19: 421-40.

4. Puder JJ, Munsch S. Psychological correlates of childhood obesity. Int J Obesity 2010; 34 Suppl 2: S37-43.

5. Pulgaron ER. Childhood obesity: a review of increased risk for physical and psychological comorbidities. Clin Therapeutics 2013; 35: A18-32.

6. Reilly JJ, Methven E, McDowell ZC, Hacking B, Alexander D, Stewart L, et al. Health consequences of obesity. Arch Dis Childhood 2003; 88: 748-52.

7. Sanderson WC. Why empirically supported psychological treatments are important. Behav Modif 2003; 27: 290-9.

8. Sackett D, Richardson W, Rosenberg W, Haynes B. Evidence-based medicine. Churchill Livingstone, London 2000.

9. Chambless DL, Hollon SD. Defining empirically supported therapies. J Consult Clin Psychol 1998; 66: 7-18.
10. Epstein LH. Development of evidence-based treatments for pediatric obesity. In: Kazdin AE WJ, ed., editor. Evidence-based psychotherapies for children and adolescents: Cambridge University Press; 2003.

11. Epstein LH, Paluch RA, Roemmich JN, Beecher MD. Family-based obesity treatment, then and now: twentyfive years of pediatric obesity treatment. Health Psychol 2007; 26: 381-91.

12. Epstein LH, Valoski A, Wing RR, McCurley J. Ten-year follow-up of behavioral, family-based treatment for obese children. JAMA 1990; 264: 2519-23.

13. Epstein LH, McCurley J, Wing RR, Valoski A. Five-yea follow-up of family-based behavioral treatments for childhood obesity. J Consult Clinical Psychol 1990; 58: 6614

14. Jelalian E, Saelens BE. Empirically supported treatments in pediatric psychology: pediatric obesity. J Pediatr Psychol 1999; 24: $223-48$

15. Epstein LH, Wrotniak BH. Future directions for pediatric obesity treatment. Obesity (Silver Spring) 2010 Feb;18 Suppl 1:S8-12.
16. Council NaMR. Clinical Practice Guidelines for the management of overweight and obesity in adults, children and adolescents including a guide for general practitioners. Commonwealth of Australia, Canberra 2003.

17. Edwards C, Nicholls D, Croker H, Van Zyl S, Viner R, Wardle J. Family-based behavioural treatment of obesity: acceptability and effectiveness in the UK. Eur J Clin Nutr 2006; 60: 587-92.

18. Croker H, Viner RM, Nicholls D, Haroun D, Chadwick P, Edwards C, et al. Family-based behavioural treatment of childhood obesity in a UK National Health Service setting: randomized controlled trial. Int J Obesity 2012; 36: 16-26.

19. Gunnarsdottir T, Sigurdardottir ZG, Njardvik U, Olafsdottir AS, Bjarnason R. A randomized-controlled pilot study of Epstein's family-based behavioural treatment for childhood obesity in a clinical setting in Iceland. Nordic Psychology 2011; 63: 6-19.

20. Obesity and overweight. WHO 2006. who.int/mediacentre/factsheets/fs311/en/. - desember 2013.

21. Cole TJ, Bellizzi MC, Flegal KM, Dietz WH. Establishing a standard definition for child overweight and obesity worldwide: international survey. BMJ 2000; 320: 1240-3. 
22. Gunnarsdottir T, Njardvik U, Olafsdottir AS, Craighead LW, Bjarnason R. Teasing and social rejection among obese children enrolling in family-based behavioural treatment: effects on psychological adjustment and academic competencies. Int J Obesity 2012; 36: 35-44. doi: 10.1038/ ijo.2011.181.

23. Karlberg J, Luo ZC, Albertsson-Wikland K. Body mass index reference values (mean and SD) for Swedish children. Acta Paediatr 2001; 90: 1427-34

24. Kovacs M. Children's Depression Inventory: Manual. Multi-Health Systems, New York 1992.

25. March JS, Parker JD, Sullivan K, Stallings P, Conners CK. The Multidimensional Anxiety Scale for Children (MASC): factor structure, reliability, and validity. J Am Acad Child Adolesc Psychiatry 1997; 36: 554-65.

26. Piers E. Piers-Harris Children Self-Concept Scale, Revised Manual. Western Psychological Services, Los Angeles 1984.

27. Smucker MR, Craighead WE, Craighead LW, Green BJ. Normative and reliability data for the children's depression inventory. J Abnormal Child Psychol 1986; 14: 25-39.

28. Craighead. Relationship of Childrens Depression Inventory factors to major depression among adolescents. Psychol Assessm 1995; 7: 171

29. Arnarson EO, Smari J, Einarsdottir H, Jonasdottir E. The prevalence of depressive symptoms in pre-adolescent school children in Iceland. Scand J Behav Ther 1994; 121 30 .
30. Olason DT, Sighvatsson MB, Smari J. Psychometric properties of the Multidimensional Anxiety Scale for Children (MASC) among Icelandic schoolchildren. Scand J Psychol 2004; 45: 429-36.

31. Gresham FM, Elliott, SN. The Social Skills Rating System. Circle Pines, MN: American Guidance Service; 1990.

32. Beck AT, Steer RA, Brown GK. BDI-II, Beck's Depression Inventory II: Manual. 2nd Edition ed. The Psychological Corporation, Harcourt, Brace, and Company, Boston 1996

33. Arnarson TO, Olason DT, Smari J, Sigurdsson JF. The Beck Depression Inventory Second Edition (BDI-II): psychometric properties in Icelandic student and patient populations. Nord J Psychiatry 2008; 62: 360-5.

34. Gunnarsdottir T, Njardvik U, Olafsdottir AS, Craighead LW, Bjarnason R. The role of parental motivation in family-based treatment for childhood obesity. Obesity (Silver Spring) 2011; 19: 1654-62. doi: 10.1038/oby.2011.59

35. Gunnarsdottir T, Njardvik U, Olafsdottir AS, Craighead L, Bjarnason R. Childhood obesity and co-morbid problems: effects of Epstein's family-based behavioural treatment in an Icelandic sample. J Eval Clin Pract 2011; 18: 465-72. doi: 10.1111/j.1365-2753.2010.01603.x.

36. Epstein LH, Roemmich JN, Raynor HA. Behavioral therapy in the treatment of pediatric obesity. Pediatr Clin North Am 2001; 48: 981-93.

37. Hamill PV, Drizd TA, Johnson CL, Reed RB, Roche AF, Moore WM. Physical growth: National Center for Health Statistics percentiles. Am J Clin Nutr 1979; 32: 607-29.
38. Panagiotopoulos C, Ronsley R, Al-Dubayee M, Brant R, Kuzeljevic B, Rurak E, et al. The centre for healthy weights--shapedown BC: a family-centered, multidisciplinary program that reduces weight gain in obese children over the short-term. Int J Environ Res Public Health 2011; 8: 4662-78.

39. Hodges EA. A primer on early childhood obesity and parental influence. Pediatr Nurs 2003; 29: 13-6.

40. Ráðleggingar um mataræði og næringarefni fyrir fullorðna og börn frá tveggja ára aldri. Lýðheilsustöð, Reykjavík 2006 .

41. Rolls BJ, Drewnowski A, Ledikwe JH. Changing the energy density of the diet as a strategy for weight management. J Am Diet Assoc 2005; 105 (5 Suppl 1): S98-103.

42. Drevenhorn E, Kjellgren KI, Bengtson A. Outcomes following a programme for lifestyle changes with people with hypertension. J Clin Nurs 2007; 16(7B): 144-51.

43. Poirier P, Giles TD, Bray GA, Hong Y, Stern JS, Pi-Sunyer FX, et al. Obesity and cardiovascular disease: pathophysiology, evaluation, and effect of weight loss: an update of the 1997 American Heart Association Scientific Statement on Obesity and Heart Disease from the Obesity Committee of the Council on Nutrition, Physical Activity, and Metabolism. Circulation 2006; 113: 898-918.

44. Grundy SM. Obesity, metabolic syndrome, and cardiovascular disease. J Clin Endocrinol Metab 2004; 89: 2595-600

\section{ENGLISH SUMMARY}

\section{Family-based behavioral treatment for obese children - Results and two year follow up}

Thrudur Gunnarsdottir ${ }^{1}$, Svavar Mar Einarsson², Urdur Njardvik ${ }^{3}$, Anna Sigridur Olafsdottir ${ }^{4,6}$, Agnes Bjorg Gunnarsdottir ${ }^{5}$,

Tryggvi Helgason ${ }^{6}$, Ragnar Bjarnason ${ }^{3,6}$

Introduction: Childhood obesity has become a worldwide epidemic and Icelandic children have not been exempt from increasing rates of obesity. Epstein's family-based behavioral treatment for childhood obesity has demonstrated favorable outcomes in research settings, but research in clinical settings has been called for. The objective of this study was to replicate and confirm the effects observed in the US research setting.

Material and methods: Participants were 84 obese children (agerange: $8-13$ years) and a participating parent. Sixty-one families completed a 12 week treatment lasting 18 weeks, and were followed for one and two years post-treatment. Measurements at baseline and end of treatment included height and weight, daily activity, daily fruit and vegetable consumption, blood pressure, blood profiles and measures of psychological well-being. Measurements also included parental height, weight and depression scores.

Results: Among treatment completers BMI-SDS (body-mass index standard deviation score) decreased significantly from pre- to posttreatment $(F(2.60)=110.31, p<0.001)$ which was maintained at one-year
$(F(2.60)=1.33, p=0.253)$ and two-years $(F(2.60)=3,19, p=0.079)$ post treatment. There was a significant reduction in blood pressure (upper: $\mathrm{t}(59)=-2.01, \mathrm{p}<0.05$, lower: $\mathrm{t}(59)=-4.00, \mathrm{p}<0.001)$. Among a subsample $(n=23)$ of participants, significant reductions were observed in fasting insulin levels, $(\mathrm{t}(22)=6.1, \mathrm{p}<0.05)$, triglycerides $(\mathrm{t}(22)=0.31, \mathrm{p}<0.05)$ and total cholesterol $(\mathrm{t}(22)=0.35, \mathrm{p}<0.05)$. Significant improvements were observed for measures of psychological well-being (depressive symptoms: $(F(1.59)=6.67, p<0.05)$; anxiety: $(F(1,57)=4.54, p<0.05)$ and children's self-concept $(F(1.59)=19.2, p<0.001)$. A significant reduction was observed in parental BMI scores from pre- to post- treatment $(F(1.59)=$ $71.54, p<0.001)$ but a significant increase was evident at one year posttreatment $(F(1.59)=41.87, p<0.001)$. Improvements were observed for measures of parental depression from pre- to post- treatment $(F(1.60)=$ 12.93, $\mathrm{p}<0.01$ )

Conclusion: Epstein's family-based behavioural treatment showed promising effects on weight status, and emotional as well as physical markers, both in the short and long term in a clinical sample of obese Icelandic children.

Correspondence: Thrudur Gunnarsdottir, thrudur.gunnarsdottir@ucdenver.edu

Keywords: childhood, obesity, family-based, treatment

${ }^{1}$ Department of Pediatrics, University of Colorado, ${ }^{2}$ BUP dogn - enhet for ungdom, Elverum, Sykehuset Innlandet, Norge, ${ }^{3}$ University of Iceland, School of Health Sciences, ${ }^{4}$ University of Iceland, School of Education, ${ }^{5}$ Landspitali University Hospital, Reykjavik, ${ }^{6}$ Department of pediatrics, Landspítali University Hospital, Reykjavik, Iceland. 